\title{
Ni-Al粒子分散めっきの表面組織とAl含有率におよぼす $\mathrm{Al}$ 粒子の表面処理とめっき条件の影響
}

\author{
伊墒 昌伸*，榎本 英彦*，小見 崇** \\ Effects of The Surface Treatment of Al Particles and Plating Conditions \\ on the Surface Structure and Al Content of Electroplated Ni-Al Dispersion Coatings
}

\author{
Masanobu IZAKI*, Hidehiko ENOMOTO and Takashi OMI**
}

\begin{abstract}
An attempt was made to electroplate a uniform and defect-free $\mathrm{N}_{1}-\mathrm{Al}$ dispersion coating which is rich in $\mathrm{Al}$ partıcle content. Since bare Al particles without surface treatment quickly dissolved into a Watts Ni bath and yielded cracked deposits, the particles were surface-treated with one of silane coupling with $\gamma$-aminopropyltrietoxy slane ( $\gamma$-APS), boiling in distlled water for $20 \mathrm{~min}$., or electroless plating with a $\mathrm{N}_{1}-\mathrm{B}$ alloy. Although these treatments strongly suppressed the dissolution of $\mathrm{Al}$ into the bath, baths containing the silane-coupled $\mathrm{Al}$ particles still yielded a cracked deposit. Deposits that were crack-free and uniform in Al particle distribution were obtained from baths containing the boiled $\mathrm{Al}$ particles or the Ni-B plated $\mathrm{Al}$ particles, the surfaces of which were composed of $\mathrm{Al}(\mathrm{OH})_{3}$ or $\mathrm{N}_{1}(\mathrm{OH})_{2}$, respectively. Among many plating variables, diluting the watts $\mathrm{Ni}$ bath and decreasing the stroke of the pumping plate were found to be quite effective in increasing the Al particle content of the coating.
\end{abstract}

Key Words : N1-Al Dispersion Coatıng, Al Surface Treatment, Plating Condition

\section{1. 緒言}

Ni-Al合金の皮膜は，優れた高温強度および高温耐食 性 ${ }^{1)}$ から, 高温用の耐食・耐摩耗性皮膜として応用が期 待され，現在すでに溶射法によって作成されている2゙。 しかし, 溶射皮膜は気孔が多い, 密着性が悪い, 皮膜が 脆い,などの問題がある。Ni-Al合金の皮膜は, $\mathrm{Al}$ が 水溶液から電析しないため, 直接合金めっきとして得る ことができないが, 近年, 水溶液から電析しない元素を 含む合金皮膜の作成法として，構成元素からなる分散めっ き皮膜を加熱により合金化する方法が検討されている ${ }^{3)}$ 。 この方法によれば，気孔がなく，素材との密着性も良い $\mathrm{Ni}-\mathrm{Al}$ 合金皮膜を作成することができると考えられる。 ところが, $\mathrm{Al}$ は電気化学的に龵なため, 分散めっきの 際にAl粒子がめっき浴中で溶解し，浴中のAlイオン濃 度を高め, めっき皮膜の組織，性質に影響をおよぼすこ とが考えられる4。Ａ１粒子の溶解抑制策として，めっき 浴の温度を下げる, pHを上げる, インヒビターを添加 する，Al粒子を被覆する ${ }^{5)}$ ，などの方法が考えられる。 このうち, インヒビターの添加については, Zn-Al分散 めっきについて検討されている5)。しかし，Al粒子の溶 解抑制策として最も効果的と考えられるAl粒子の被覆

* 大阪市立工業研究所（二536 大阪府大阪市城東区森之宮1-650)

Osaka Munıcipal Tech. Res. Inst. (6-50, Morınomiya 1-chome, Joto-ku, Osaka-shi, Osaka 536)

**大阪府立大学工学部 (干591 大阪府堺市百舌鳥梅町4-804) College of Eng., Univ. of Osaka Pref. (804, MozuUmemachı 4-cho, Sakal-shı, Osaka 591)
について検討した例は見当たらない。

そこで, 本研究では均一なNi-Al粒子分散めっき皮膜 を得るため, Al粒子の溶解抑制策としててAl粒子の表面 処理を行い, このAl粒子の表面処理がめっき浴中での $\mathrm{Al}$ 溶解量およびNi-Al粒子分散めっき皮膜の析出状態, $\mathrm{Al}$ 含有率に及ぼす影響を調べた。Al粒子の表面処理と して煮沸処理, 無電解Niめっき処理, 化成処理を選択 した。その結果, Al粒子に煮沸処理, 無電解Niめっき 処理を施すことにより, 均一なNi-Al粒子分散めっき皮 膜を作成することができた。しかし，皮膜中のAl粒子 含有率が少なかったため, Ni-Al粒子分散めっきのAl 粒子含有率におよぼす電解条件の影響についても調べ た。

\section{2. 実験方法}

\section{2. $1 \mathrm{Al}$ 粒子の表面処理}

$\mathrm{Al}$ 粒子は東洋アルミニウム(侏製AC5005で, 純度は99.3 \%以上, 平均粒子径は $3.93 \mu \mathrm{m}$ である。このAl粒子を そのまま，むしくは以下のいずれかの処理を施して実験 に用いた。

（煮沸処理）Al粒子を $0.05 \mu \mathrm{S} / \mathrm{cm}$ 以下の蒸留純水中で 20分間煮沸後, ろ別し, 蒸留純水で数回洗浄してから自 然乾燥させた。

（化成処理）化成処理としてシランカップリング処理を 行った。シランカップリング剂としては東京化成工業(侏) 製 $\gamma$-アミノプロピルトリエトキシシラン（ $\gamma$-APS）を 用いた。シランカップリング液（ $\gamma$-APS 3 vol\%, 蒸 留純水 $3 \mathrm{vol} \%$ ，エ夕ノール94vol\%）にAl粒子を添加 
し $30^{\circ} \mathrm{C}$ で16時間かく拌放置した後, ろ別し，エタノール と蒸留純水で数回ずっ洗浄してから自然乾燥させた。 （Ni無電解めっき処理）奥野製薬工業侏製OPC-50, OPC-150を用いてAl粒子表面に触媒を付与した後，奥 野製薬工業㑣製トップケミアロイB-1を用いてNi-B無 電解めっきを 1 時間行った。重量变化から求めた平均めっ き膜厚は約 $0.12 \mu \mathrm{m}$ であった。

\section{2 分散めっきの標準条件}

実験にはNiSO $\cdot 6 \mathrm{H}_{2} \mathrm{O} 240 \mathrm{~g} / \mathrm{L}, \mathrm{NiCl}_{2} \cdot 6 \mathrm{H}_{2} \mathrm{O}$ $45 \mathrm{~g} / \mathrm{L}, \mathrm{H}_{3} \mathrm{BO}_{3} 30 \mathrm{~g} / \mathrm{L}$ 組成のワット Ni浴を用いた。めっ き浴は特級試薬を蒸留純水に溶解して作成した。この浴 に処理後の重量で $20 \mathrm{~g} / \mathrm{L} の \mathrm{Al}$ 粒子を添加し, 浴温 $50^{\circ} \mathrm{C}$, $\mathrm{pH} 4.0$, 陰極電流密度 $4 \mathrm{~A} / \mathrm{dm}^{2}$ の条件で, 2 枚のNi陽 極の間に置いたステンレス鋼板 $(4 \mathrm{~cm} \times 4 \mathrm{~cm})$ 上にめっ きした。1 Lビーカ一を電解槽しして用い，めっき谷は 100r.p. mのシンクロナスモーターで駆動した, ストロー ク $25 \mathrm{~mm}$ のプレートポンパーによりかく捧した。めっき 皮膜の厚さは約 $50 \mu \mathrm{m}$ とした。

\section{3 めっき浴，めっき皮膜の分析}

めっき浴中の $\mathrm{Ni}, \mathrm{Al}$ 濃度は原子吸光法で求めだ。 き皮膜のAlおよびB含有率は高周波プラズマ発光分光分 析装置 (以後ICP分析) により求めた。

\section{4 X線回折，X線光目子分光分析，表面の観察}

$\mathrm{X}$ 線回折はCuK $\alpha(30 \mathrm{kV}, 15 \mathrm{~mA})$ によるディフラ クトメーター法で行い, JCPDSカードにより同定した。 X線光電子分光分析（以後XPS）は，侏島津製作所製
ESCA-750を用い，MgK $\alpha$ で行った。測定試料室は6.6 $\times 10^{-5} \mathrm{~Pa}$ 以下に保ち, 結合エネルギー值はC $1 \mathrm{~s}$ のピー クエネルギー值を285.0 eVとして校正した。めっき皮膜 およびA1粒子の観察上分析には走査型電子顕微鏡（SE M) とエネルギー分散型X線分光器（EDS）を用いた。

\section{3. 結果と考察}

\section{1 Al粒子の表面処理の勃果}

無処理のAl粒子および煮沸，シランカップリング， Ni-B無電解めっきの各処理を施したAl粒子のめっき浴 中への溶解量および得られためっき皮膜中のAl含有率 を表 1 に, 代表的な表面組織の反射電子組成像を图 1 に 示した。通常の 2 次電子像ではNiとAlを明瞙に区別す ることができなかった。そこで，2 次電子像よりも組成 によるコントラスト差の大きい反射電了組成像により観 察した。图1の白い部分はNi, 黒い部分はAlを示して いる。表 1 の, Al溶解量は, 無処理および処理後のA1 粒子 $20 \mathrm{~g} / \mathrm{L}$ を浴に添加し，24時間放置後のめっき浴中の $\mathrm{Al}$ 濃度である。

無処理のA1粒子を用いた場合，Al粒子の大部分はめっ き浴中に分散せず，ビーカーの壁やめっき浴上に凝集し た。しかし, 無処理のA 1 粒子添加直後の浴加らのめっ き皮膜はAlを3.6at\%含有していた。この場合のめっき 皮膜は図 1 に示すように連続であるが、凹凹がかなり大 きい。これは，共析したAl粒子上にNiが析出したため と考えられる。添加後24時間放置しためっき浴から得ら

Fig. 1 Scanning electron micrographs of surface of $\mathrm{Ni}-\mathrm{Al}$ composite coatings.

(a)Al particles without surface treatment

(b)Al particles boiled in water

(c)Al particles treated with silane coupling treatment: (1)crack, (2) Al particles

(d)Al particles electroless plated with Ni-B alloy

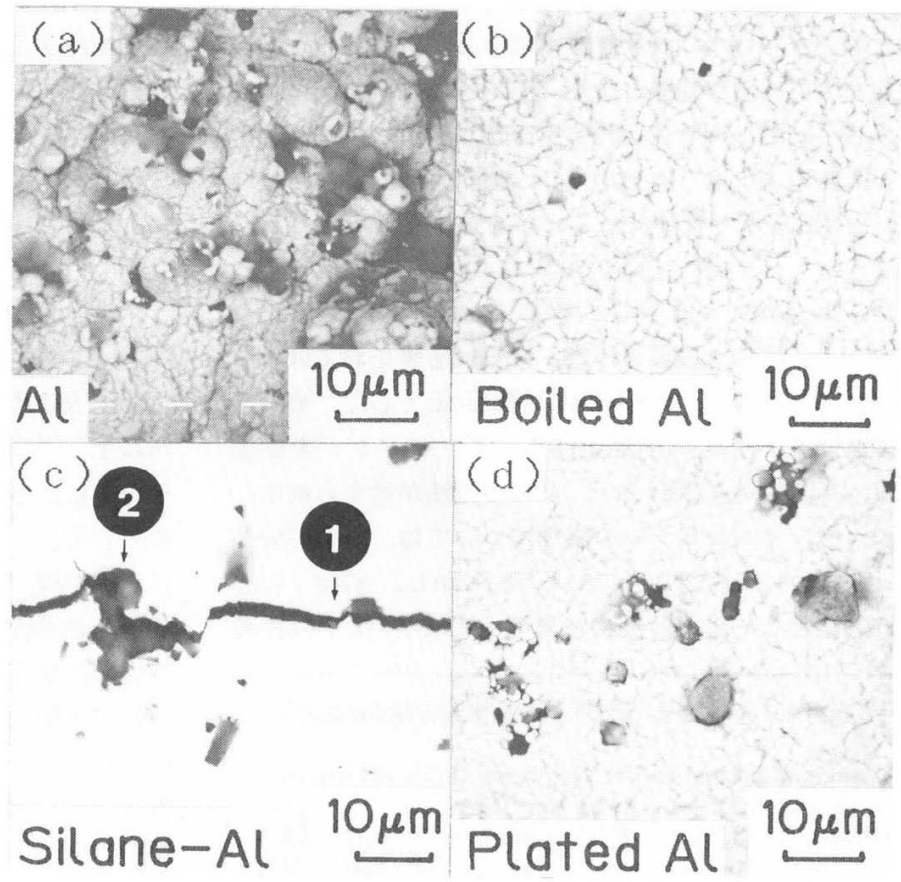


Table 1 Performance of Al particles in Watts Ni bath, added with $20 \mathrm{~g} / \mathrm{L}$ of $\mathrm{Al}$ particles.

\begin{tabular}{l|c|c|c|c|c}
\hline \multicolumn{2}{c|}{$\begin{array}{c}\text { Concentration in Bath } \\
\text { after 24hours }\end{array}$} & $\mathrm{Al}$ & $\begin{array}{c}\text { Boiled } \\
\mathrm{Al}\end{array}$ & $\begin{array}{c}\text { Silane } \\
\text { coupled } \\
\mathrm{Al}\end{array}$ & $\begin{array}{c}\text { Ni-B } \\
\text { plated } \\
\mathrm{Al}\end{array}$ \\
\hline $\mathrm{Ni}(\mathrm{g} / \mathrm{L})$ & $64.7 *$ & 16.8 & 63.5 & 64.1 & 64.7 \\
\hline $\mathrm{Al}(\mathrm{ppm})$ & $\mathrm{N} . \mathrm{D} . *$ & 18000 & 24 & 28 & 8 \\
\hline \multicolumn{2}{l|}{$\mathrm{Al}(\mathrm{at} \%)$ in deposit } & $3.6 * *$ & 0.87 & 0.79 & 2.1 \\
\hline
\end{tabular}

* before addition of $20 \mathrm{~g} / \mathrm{L} \mathrm{Al}$ particle, N.D. : Not detected ** Just after addition of $\mathrm{Al}$ particles

れためっき皮膜は割れてはくりしており，一部は通電中 に脱落した。これは表 1 に示すように, Al粒子無添加 のワットNi浴ではAlは検出できないが，24時間放置浴 は約 $18 \mathrm{~g} / \mathrm{L} の \mathrm{Al}$ を含有し，添加したAl粒子 $(20 \mathrm{~g} /$ L）の約 $90 \%$ が溶解していた。ワットNi浴中のAlイオ ンはめっき皮膜の電着応力を増加させ, 密着力を低下さ せることが知られているい。このことから，めっき皮膜 が割れたのはAl粒子が溶解し，めっき浴中のAlイオン 濃度が増大したためと考えられる。一方, めっき浴の $\mathrm{Ni}$ 濃度はA 1 粒子添加前の約 $64.7 \mathrm{~g} / \mathrm{L}$ から約 $16.8 \mathrm{~g} / \mathrm{L}$ に減 少している（表 1)。24時間放置しためっき浴からろ別 したAl粒子は添加前の灰色が黒っぽく変色し, SEM観 察の結果, 粗大化していた。この外観の変化は, $\mathrm{Al}$ 粒 子の溶解に伴ってNiがAl粒子上に析出したためと考え られ, 浴中の Ni濃度の低下はNiがAl粒子上に置換析出 したためと考えられる。

$\mathrm{Al}$ 粒子に煮沸処理, シランカップリング処理, Ni-B 無電解めっき処理を施すことにより，Al溶解量は著し く減少した (表 1 )。Al溶解量は, 無処理のAl粒子の $18000 \mathrm{ppm}$ に比べ，煮沸したAl粒子（以後煮沸粒子）は $24 \mathrm{ppm}$, シランカップリング処理したAl粒子（以後シ ラン粒子）は28ppm，また無電解NiめっきしたAl粒子 （以後めっき粒子）は $8 \mathrm{ppm}$ に減少した。また，Al粒子 の溶解量の減少と共に, NiのAl粒子への置換析出も抑
制され，無処理の $\mathrm{A} 1$ 粒子では浴中の $\mathrm{Ni}$ 浱度は約 $3 / 4$ に減 少したのに対して，煮沸粒子では約 $1.8 \%$ ，シラン粒子 では約 $1 \%$ 減少しただけで，めっき粒子では変化しなかっ た。図 1 に示すように，煮沸粒子，めっき粒子を用いた めっき皮膜では, 粒子はNiマトリックス中に分散して 共析していた。しかし，シラン粒子では，めっき皮膜は 平滑であるが, クラック（図中矢印(1)）が認められ，粒 子は数個ずつ凝集して共析していた（図中矢印(2)。

また，無処理のAl粒子では，共析したAl粒子上に $\mathrm{Ni}$ が析出するため，露出したAl粒子は少なかった。しか し，煮沸処理，めっき処理したAl粒子では，Al粒子は 露出しており，粒子上にNiは析出していない。Foster らは, 分散粒子が導電性の場合には粒子上にあめっきが 析出するが, 非導電性の場合には粒子上には析出しない ことを報告している ${ }^{6)}$ 。このことから，煮沸処理，めっ き処理したAl粒子上にNiが析出していないことは,こ れらのAl粒子が非導電性粒子として挙動していること を示唆している。Al粒子自身は導電性であるので, 非 導電性粒子として挙動したのは, 煮沸処理, めっき処理 により $\mathrm{Al}$ 粒子上に生成された被覆首によるあのと考え られる。そこで，この被覆首を明らかにするために，処 理した粒子の構造を調べた。

\section{2 表面処理したAl粒子の構造}

煮沸粒子，めっき粒子の代表的なX線回折パターンを 図 2 に示す。煮沸粒子では, $\mathrm{A} 1$ の回折線の他に $d=2.22$ $\AA ̊ 丿 1.85 \AA ， 1.73 \AA$ に微小な回折線が認められた。これ らの回折線は $\mathrm{Al}(\mathrm{OH})_{3}{ }^{7)}$ により指数付けすることがで きた。これより，煮沸処理したAl粒子の表面には $\mathrm{Al}(\mathrm{OH})_{3}$ が生成していると考えられる。煮沸処理した $\mathrm{Al}$ 粒子か渄導電性粒子として挙動したのは, このAl $(\mathrm{OH})_{3}$ によるあのと考えられる。

めっき粒子では, $\mathrm{Al}$ の回折線の他にブロードな $\mathrm{Ni} の$ (111), (200)回折線だけが認められる。このめっき皮膜 は, ICP分析の結果, Bを2.8at\%含有しており, 平衡状
Fig. 2 X-ray diffraction patterns of $\mathrm{Al}$ particles.

a) electroless plated with $\mathrm{Ni}-\mathrm{B}$ alloy

b) boiled in water for $20 \mathrm{~min}$.

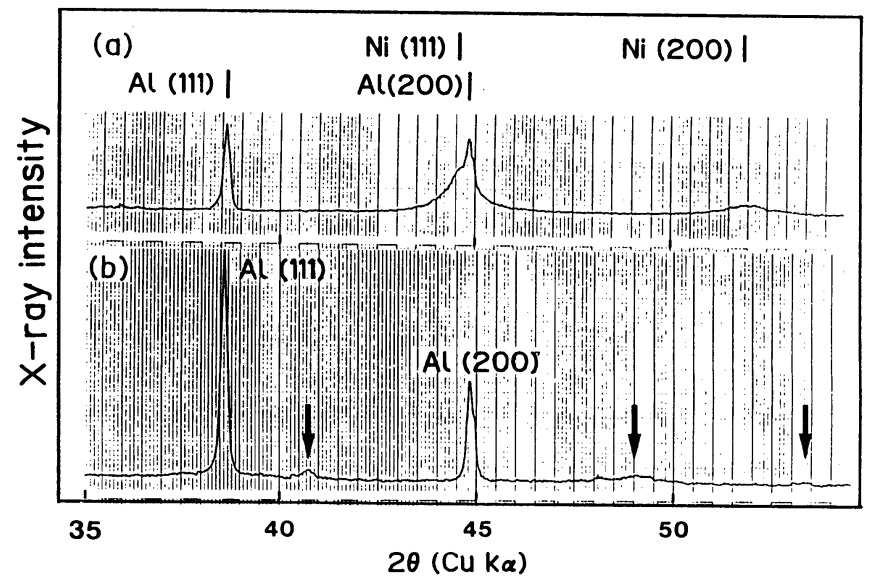




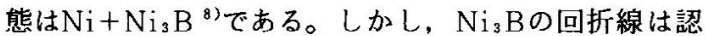
められず, $\mathrm{Ni}$ 無電解めっき皮膜はNi過飽和固溶体と考 えられる。図 3 にめっき粒子の 2 次電子像 (S. E. I) とNiの分布を示す。無処理のAl粒子の表面は滑らかで あるが，めっき粒子表面は約 $0.04 \mu \mathrm{m}$ の微細な山几状で， Ni份布像に見られるようにほぼ全面にNiが存在してお り，A1粒子はほぼ完全にNi過飽和固溶体層で被覆され ている。

$\mathrm{Ni}$ 過飽和固溶体む $\mathrm{Al}$ 粒子も良導体である。このこと からめっき粒子が非導電性粒子として挙動したのは，めっ き粒子の極表面層によると考えられる。そこで， ESCA を用い, めっき粒子の表面を調べた。図 4 にNi 2 p XPSスペクトルを示す。金属状態を示す $852.2 \mathrm{~V}$ 'のピー

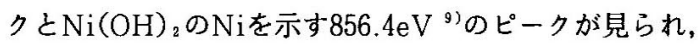
$856.4 \mathrm{eV}$ のピークの方が852.2eVのピークよりあかなり 强い。このようにNi過飽和固溶体表面には $\mathrm{Ni}(\mathrm{OH})_{2}$ が 生成しており,この $\mathrm{Ni}(\mathrm{OH})_{2}$ が絶緑首として作用する ために，めっき粒子も非導電粒子として挙動したものと 考えら机る。

以上のように，A1粒子に著沸処理，めっき処理を施 すことによりAl粒子の溶解は抑制でき，連続なめっき 皮膜を安定に作成することができた。一般に, 高温材料 として用いられている $\mathrm{Ni}-\mathrm{Al}$ 合金は約15at\%のAlを含 有しているが，得られたNi-Al分散めっきのAl含有率 は，㟟沸粒子で $0.87 \mathrm{at} \%$ ，めっき粒子で $2.1 \mathrm{at} \%$ と少な 加った（表 1 参照）。分散めっきの分散粒了含有率は, めっき浴の組成，電解条件と強く関係することが報告さ れている。そこで，めっき皮膜中のAl含有率を高める
ための電解条件の設定を目的として，めっき浴の組成, 電解条件の検討を行った。

\section{3. $3 \mathrm{Al}$ 粒子含有率におよほす浴組成，軍解条件の 影篅}

めっき皮膜中のAl粒子含有率におよぼす浴の $\mathrm{pH}$ ，陰 極電流密度，かく拌プレートのストローク，めっき浴の 濃度の影響を調べた。その際, めっき浴の濃度は蒸留純 水で希釈して変化させ，浴のpHは希硫酸で調整した。 これらの因子の内一つだけ変化させ, 他は標準条件のま まとして実験した結果を图 5 に示す。図中のは者沸粒 子、○はめっき粒子の含有率である。

めっき浴の $\mathrm{pH}$ は3.0 4.0の範囲，電流密度は $1 \sim 10 \mathrm{~A}$

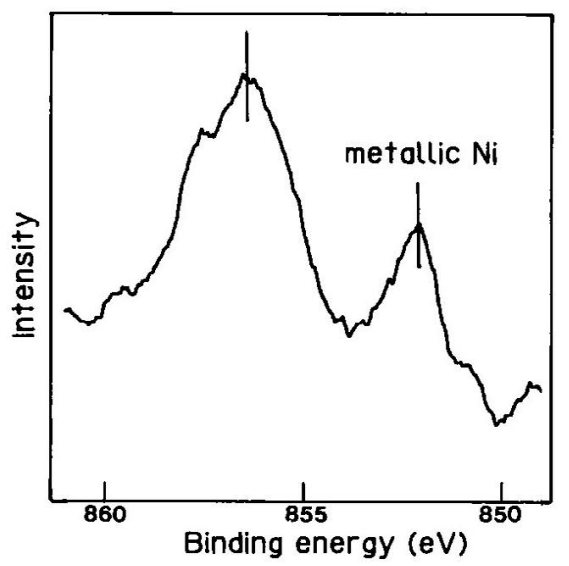

Fig. 4 Ni $2 p$ 3/2 XPS spectra of Al particles electroless plated with Ni-B alloy.

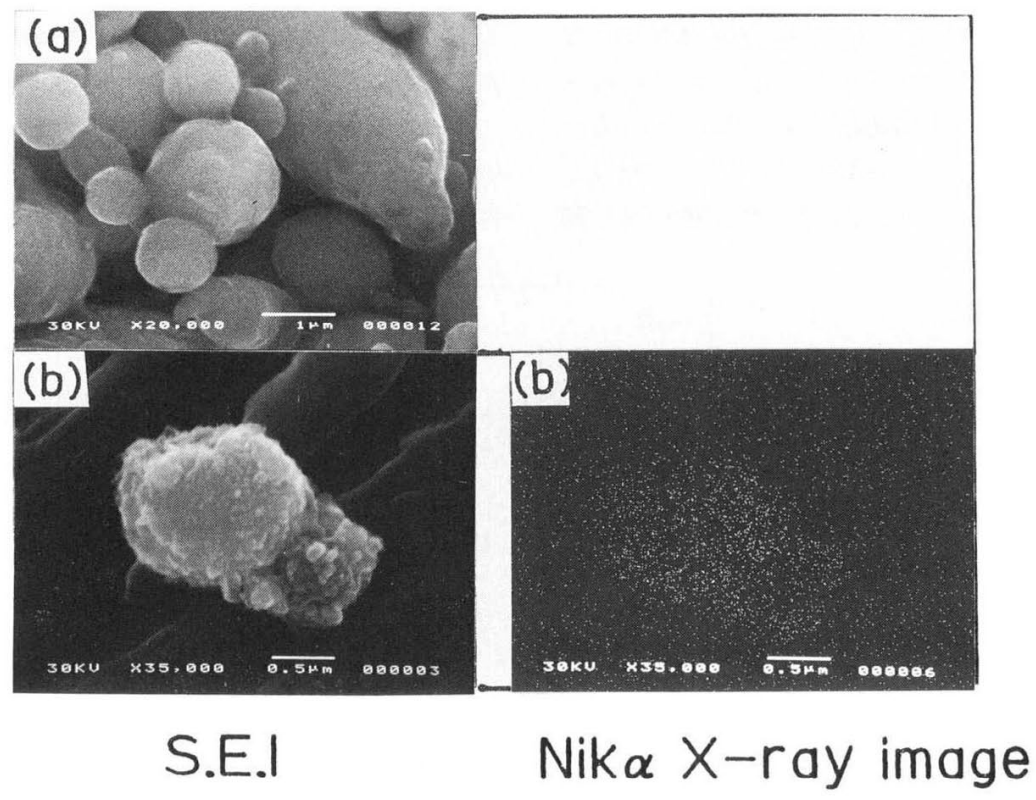

Fig. 3 Microstructures and $\mathrm{Ni}$ distribution of $\mathrm{Al}$ particles.

a) without surface treatment b) electroless plated with $\mathrm{Ni}-\mathrm{B}$ alloy 


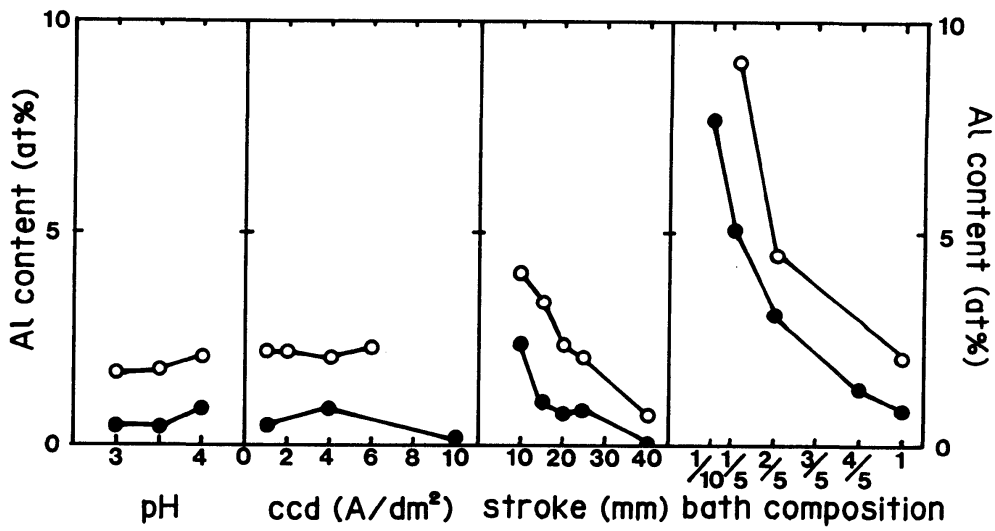

Fig. 5 Effects of $\mathrm{pH}$, cathode current density, stroke of pumping plate, bath composition on $\mathrm{Al}$ content of $\mathrm{Ni}-\mathrm{Al}$ composite coatings. Standard conditions :

bath composition : $\mathrm{NiSO}_{4} \cdot 6 \mathrm{H}_{2} \mathrm{O} 240 \mathrm{~g} / \mathrm{L}, \mathrm{NiCl}_{2} \cdot 6 \mathrm{H}_{2} \mathrm{O} 45 \mathrm{~g} / \mathrm{L}, \mathrm{H}_{3} \mathrm{BO}_{3} 30 \mathrm{~g} / \mathrm{L}$. plating conditions : $\mathrm{pH} 4.0,4 \mathrm{~A} / \mathrm{dm}^{2}$, stroke $25 \mathrm{~mm}$.

Boiled $\mathrm{Al}$ particle, OElectroless plated $\mathrm{Al}$ partricle

$/ \mathrm{dm}^{2}$ の範囲で変化させたが, 含有率に大きな変化は認 められなかった。ストロークは $10 \mathrm{~mm}$ から $35 \mathrm{~mm}$ まで変 化させた。ストローク $35 \mathrm{~mm}$ では含有率は少なく，共析 している粒子あ小さいが，ストロークが小さくなるほど 含有率は増大し，大きな粒子の共析あ認められた。これ は, 多くの分散めっきで報告されているように，かく捧 が強いほど，また粒子が大きいほど，粒子がめっき液の 流れや重力場の影響を受けるため共析しにくくなるた め $^{6) .10)}$ 之考えられる。

めっき浴の希釈はA1粒子含有率にきわめて大きな影 響をおよぼした。乽沸粒子(○)では，皮膜のAl粒子含 有率は標準組成の浴からの皮膜に対して，4/5希釈で約 1.5倍，2/5で約 3.5 倍，1/5で約 6 倍，1/10では約 10 倍に 達した。めっき粒子 $(O)$ であ $1 / 5 に$ 希釈することによっ てAl粒子含有率は約4.4倍の9.2at\%に増加した。非導電 粒子については，粒子の $\zeta$ 一電位が大きいほど含有率が 多いこと ${ }^{11}, \zeta$-電位はめっき浴濃度が低いほど大きい こと ${ }^{10)}$ が報告されている。惹沸粒子，めっき粒子共， $\mathrm{Al}$ 粒子の構造で示したように, 非導電粒子として挙動して いることから, めっき浴濃度の低下に伴いら-電位が大 きくなったために，Al粒子含有率が増大したあのと考 えられる。

\section{4. 結言}

$\mathrm{Ni}-\mathrm{Al}$ 粒子分散めっきの析出状態とAl粒子含有率に およぼす $\mathrm{Al}$ 粒子の煮沸処理，シランカップリング処理, $\mathrm{Ni}$ 無電解めっき処理の影響および浴組成, 電解条件の 影響について検討した。その結果, 以下のことが明らか になった。

1. 無処理のAl粒子はワットNi浴中に分散せず, 溶解 した。Al粒子に煮沸処理, シランカップリング処理, $\mathrm{Ni}-\mathrm{B}$ 無電解めっき処理を施すことにより, Al粒子の溶
解は著しく抑制された。煮沸処理, Ni-B無電解めっき 処理したAl粒子を添加したワットNi浴からは, 連続で 平滑なNi-Al粒子分散めっき皮膜が得られた。しかし， シランカップリング処理したAl粒子を添加したワット $\mathrm{Ni}$ 浴からは，割れためっき皮膜が得られた。

2. 募沸処理した $\mathrm{Al}$ 粒子の表面は $\mathrm{Al}(\mathrm{OH})_{3}$ からなって いた。Ni-B無電解めっき処理したAl粒子は, Ni過飽和 固溶体層でほぼ完全に被覆されており，その表面は $\mathrm{Ni}(\mathrm{OH})_{2}$ からなっていた。

3. Ni-Al粒子分散めっきのAl含有率は, 浴の $\mathrm{pH}$, 陰 極電流密度にはあまり依存しなかったが, めっき浴のか く拌の強さ，めっき浴の濃度に大きく依存した。

終わりに，本研究を行うにあたり無電解めっき処理液, 触媒付与液の提供およびICP分析をして頂いた奥野製薬 㑣と同社川岸重光氏，Al粒子を提供頂いた東洋アルミ ニウム(俶，浅野化学産業(俶に謝意を表します。

(1989-5-25 受理)

\section{文献}

1) 山口正治, 馬越佑吉; 金属間化合物, p. 153 (日刊工業新聞 社, 1986)

2 ）長坂秀雄 ; 日本金属学会報, 22, 1021 （1983）

3 ) F. J. Honey, V. Wride, E. C. Kedward ; Plating and Surface Finishing, 73, (10), 42 (1986)

4) 電気鍍金研究会編 ; めっき教本, p. 85（日刊工業新聞社, 1986)

5 ）吉原敬久，木村 竬，原田俊一 ; 鉄と鋼，66，779（1980）

6) J. Foster, B. Cameron ; Trans. Inst. Met. Fin., 54, 178 (1976)

7) JCPDS PDF 20-11

8 ）日本金属学会 ; 金属データブック, p. 561（丸善, 1984）

9 ) Handbook of X-ray Photoelectron Spectroscopy, p. 81 (Perkin-Elmer, 1978)

10）増子 昇, 虫明克彦; 金属表面技術，31，523（1980）

11) T. Isao, T. Hirai ; DENKI KAGAKU, 46, 544 (1978) 